\title{
HUMAN MISADVENTURE IN ANAESTHESIA
}

\author{
J.E. Utting, T.C. Gray and F.C. Shelley
}

THIS PAPER is based on data obtained by two of the authors (T.C.G. and F.C.S.) from the records of the anaesthetic accidents reported to the Medical Defence Union of the United Kingdom (M.D.U.) during the eight years from 1970 to 1977. The M.D.U. represents some two-thirds of the medical practitioners in the United Kingdom and Eire and many more in Australia, Canada, and other countries. Its total strength, including dental practitioner members, is 87,000 .

No member is bound to report an accident and this account is, therefore, in no way comprehensive. It is probable, however, that with one important proviso most of the more serious mishaps are reported, although the incidence of reporting of minor matters such, for example, as the loss of a tooth, is probably relatively low.

The proviso about reporting serious mishaps is necessary because it is probable that many deaths were not reported because it was realised that they were due to the disease concerned, rather than to anaesthesia. Though the records are not comprehensive, they probably represent a reasonably reliable account of situations in which the anaesthetist has realised that something unfortunate or disastrous has happened to a patient and that, as a result, there is a danger of legal action. This, in itself, seems to make them of some interest.

It must also be pointed out that the judgements on what happened in these cases, though expert, are still liable to dispute. All that can be said in this regard is that the judgements are those of peers in the speciality who viewed the facts with particular reference to what might be expected in a court of law. Doubtless some few of these individual judgements will be wrong but almost cer-

J.E. Utting, M.A., M.B., F.F.A.R.C.S., Professor of Anaesthesia, University of Liverpool. Royal Liverpool Hospital. P.O. Box 147. Liverpool L69 38X. England. T.C. Gray, C.B.E., M.D., F.R.C.S., F.R.C.P. F.F.A.R.C.S.. Treasurer, Medical Defence Union. F.C. Shelley. F.F.A.R.C.S.. D.A.. Under-secretary, Medical Defence Union.

This paper is a resume of a paper given by one of the authors (J.E.U.) to the Atlantic Regional Meeting of the Canadian Anaesthetists' Society in St. John's on 30tin September, 1978. tainly, in the majority of cases, they will be correct.

\section{ACCIDENTS REPORTED}

The total number of anaesthetic accidents reported to the M.D.U. over the eight years 1970 to 1977 is shown in Table 1 . There was a total of 602 accidents (in the order of one every five days) produced by something in the order of 2.000 anaesthetists who are members of the Union.

Some of these accidents are relatively trivial; one in five of them, for example, concerns damage to teeth; this may be inconvenient and annoying to the patient but it is not a matter of life and death, nor of serious permanent injury, although when complex orthodontic treatments have been involved these accidents may be expensive as far as litigation is concerned. As has been pointed out. the incidence of reporting is probably low; many anaesthetists damage teeth but avoid medico-legal trouble, especially if in appropriate circumstances they have forewarned the patient and if they seek immediate advice from a dental colleague if damage has been done.

Most cases, however, are far from trivial. There were 108 cases involving neurological damage. Of these 71 were cases of crebral damage and these. together with the 277 deaths, con-

TABLE 1

ANAESTHETIC ACCIDENTS RePorted TO M.D.U., 1970-1977

\begin{tabular}{lr}
\hline \hline $\begin{array}{l}\text { Deaths } \\
\text { Damage to teeth }\end{array}$ & 277 \\
$\begin{array}{l}\text { Neurological damage } \\
\text { Cerebral }\end{array}$ & 127 \\
$\quad$ Spinal cord & \\
$\quad$ Peripheral nerves 29 & \\
Superficial thrombosis & 108 \\
throrabophlebitis & \\
Epidural foreign bodies & 32 \\
$\quad$ (needles and catheter tips) & 27 \\
Awareness & 11 \\
Extravasation of injected drugs & 8 \\
Pneumothorax & 5 \\
Burns & 3 \\
Others & 4 \\
& Total \\
& 602 \\
\hline
\end{tabular}


stitute 60 per cent of all the cases; an account of these two groups will constitute the main part of this paper. Other cases of neurological damage involved the spinal cord. In this connection, for example, a patient developed the anterior spinal artery syndrome following epidural analgesia in which, initially, there had been an accidental dural tap with leakage of cerebro-spinal fluid. The epidural was established with lignocaine and adrenaline at the same level and there was marked systolic hypotension. As might be expected, damage to the peripheral nerves is still common and, in this connection. it may be said that it is remarkable how often, even now, the ulnar nerve is injured by pressure. The risk of nerve damage. moreover, is not confined to the period of operation; there is considerable danger during the recovery and even later postoperatively.

Superficial thrumbosis and thrombophlebitis remains a problem; and this problem has, perhaps, been exacerbated by the use of diazepam. The reports of 27 cases in which an epidural foreign body has been introduced shows an interesting side-effect on the increased popularity of this form of analgesia, especially in midwifery.

There were 11 cases of awareness. This unpleasant condition is now probably less common than it was: this is just as well, since it can have very severe psychiatric sequelae. There has been an increasing realization of its importance and probably anaesthetists have become more careful and meticulous in their technique in an effort to avoid it

Extravasation of injecsed drugs and burns are each a small group, though certainly complaints of both have been made for many years. Pneumothorcix, however, is relatively new. It can be caused, for example. by mis-connecting anaesthetic circuits and screwing expiratory valves hard down so that the lungs are subjected to gas at high pressure.

Finally. it must be mentioned that there is a relatively tiny number of other accidems. In this case the group included arterial thrombosis, dislocated temporo-mandibular joint, corneal abrasion and a case in which a suction tube was left in the trachea.

\section{DEATHS}

During the years 1970 to 1977 a total of 277 anaesthetic deaths was reported to the M.D.U. The presumptive causes of these deaths are given in Table I1. It has already been stated that re-
TABLE II

Factors lNvolved in 277 Deaths Reported to M.D.U., 1970-1977

\begin{tabular}{|c|c|c|}
\hline & No. of Cases & $\%$ \\
\hline Faulty technique & 120 & $(43.3)$ \\
\hline Co-existing disease & 34 & $(12,3)$ \\
\hline Unknown & 29 & $(10.5)$ \\
\hline Failure of postop. care & 28 & $(10.1)$ \\
\hline Drug overdose & 15 & $(5.4)$ \\
\hline Drug sensitivity & 12 & (4.3) \\
\hline Halothane hepatic failure (?) & 12 & $(4.3)$ \\
\hline Hyperthermia & 8 & (2.9) \\
\hline Failure of preop. assessment & 5 & $(1.8)$ \\
\hline Blood loss and hypotension & 5 & $(1.8)$ \\
\hline Drug error & 4 & $(1.4)$ \\
\hline Embolism & 3 & (1.1) \\
\hline \multirow[t]{2}{*}{ Anaesthesiologist failure } & 2 & \\
\hline & al 277 & \\
\hline
\end{tabular}

porting may be incomplete and that this may be particularly so in the case of deaths classified as being due to co-existing disease. Doubtless on many occasions patients were anaesthetized in the full knowledge that the possibility of death was a very real one. When a patient died the death might well have been reported to the coroner but not to the Union, if it were thought that the relatives of the patient realized that no error was involved in the death.

\section{Cerebral Damage}

The causes of the 71 cases of cerebral damage are given in Table III. Severe cerebral damage resulting from anaesthesia can be more appalling than death. The relatives may be subjected to the harrowing experience of seeing the patient living on with varying degrees of intellectual impair-

TABLE III

Factors Involved in 71 Cases of Cerebral Damage REPORTED TO M.D.U., 1970-1977

\begin{tabular}{lrr}
\hline & No. of Cases & \multicolumn{1}{c}{$\%$} \\
\hline Faulty technique & 43 & $(60.6)$ \\
Failure of postop. care & 5 & $(7.0)$ \\
Unknown & 7 & $(9.9)$ \\
Drug sensitivity & 4 & $(5.6)$ \\
Co-existing disease & 3 & $(4.2)$ \\
Drug overdose & 3 & $(4.2)$ \\
Anaesthesiologist failure & 3 & $(4.2)$ \\
Drug error & 1 & $(1.4)$ \\
Blood loss & 1 & $(1.4)$ \\
Clot in by-pass & 1 & \\
& &
\end{tabular}


ment, the worst of which will leave the patient little better than a vegetable.

All anaesthetists of experience have seen such cases, but probably the suffering implied for both patient and relatives can only be appreciated by those who have experienced it. One further point must be made, however, even if it be on a purely materialistic level. The sum awarded in damages to some of the most unfortunate patients has, by the standards of English litigation, been enormous.

Modern resuscitative techniques must surely represent one of the great advances in modern medicine: many are now alive and well who would otherwise be dead. Nevertheless there are undesirable side-effects of resuscitation as of any other medical technique. In this context. too, the effect of ill-advised resuscitation must be mentioned. Indiscriminate charity has been described as a device of the devil and so, too, must be injudicious resuscitation.

\section{Major Catastrophes}

A comparison of Table II with Table III shows at once that the two lists of causes (deaths and cerebral damage respectively) are closely similar; so similar, indeed, that it seems both possible and reasonable to deal with them together, regarding both as major catastrophes. The pooled data of 348 cases of death or cerebral damage are, accordingly, shown in Table IV.

\section{Faulty rechnique}

The most striking fact which emerges from Table IV is that it was deemed that nearly half the

TABLE IV

Major Catastrophies: Causes of Death and Ceregral Damage Treated Tocether

\begin{tabular}{lrr}
\hline & No. of Cases & \multicolumn{1}{c}{$\%$} \\
\hline Faulty technique & 163 & $(46.8)$ \\
Co-existing disease & 37 & $(10.6)$ \\
Unknown & 36 & $(10.3)$ \\
Failure of postop. care & 33 & $(9.5)$ \\
Drug overdose & 18 & $(5.2)$ \\
Drug sensitivity & 16 & $(4.6)$ \\
Halothane hepatic failure (?) & 12 & $(3.4)$ \\
Hyperthernia & 8 & $(2.9)$ \\
Blood loss & 6 & $(1.7)$ \\
Failure of preop. assessment & 5 & $(1.4)$ \\
Drug error & 5 & $(1.4)$ \\
Anaesthesiologist failure & 5 & $(1.4)$ \\
Embolism & 3 & $(0.9)$ \\
Clot in by-pass & 1 & $(0.3)$ \\
& 348 & \\
\hline
\end{tabular}

TABLE $V$

Cases of Faulty Technioue Resultino in Death or Cerebral Damage

\begin{tabular}{|c|c|c|}
\hline & No, of Cases & $\%$ \\
\hline \multicolumn{3}{|l|}{ General Anaesthesia } \\
\hline Endotracheal intubation & so & $(30.7)$ \\
\hline Misuse of apparatus & 40 & $(24,5)$ \\
\hline Acid aspiration syndrome & 22 & $(13.5)$ \\
\hline Induced hypotension & 16 & $(9.8)$ \\
\hline Hypoxia & 11 & $(6,7)$ \\
\hline $\mathrm{N}_{2} \mathrm{O}$ in place of $\mathrm{O}_{2}$ & 6 & $(3.7)$ \\
\hline Obstructed airway & 4 & $(2.4)$ \\
\hline $\mathrm{CO}_{2}$ in place of $\mathrm{O}_{2}$ & 4 & (2.4) \\
\hline Halothane with adrenaline & 3 & $(1.8)$ \\
\hline Accidental pneumothorax & 2 & (1.2) \\
\hline \multicolumn{3}{|l|}{ Local Anaesthesia } \\
\hline Epidural & 5 & $(3.0)$ \\
\hline & Total 163 & \\
\hline
\end{tabular}

cases of death or cerebral damage (47 per cent) were due to faulty technique. An attempt at classification of these faults in technique is shown in Table $V$. Such a classification cannot. of course, be entirely consistent; thus error of tracheal intubation figures in the Table as an entity separate from hypoxia, despite the fact that the former will certainly result in the latter. Despite this sort of difficulty the classification. though far from perfect, seems to convey the essentials of the various problems.

The most common fault in technique was concerned with tracheal intubation and usually resulted in the tracheal tube being placed in the oesophagus. This sort of accident with tracheal tubes was responsible for 37 deaths and 13 cases of cerebral damage during the eight-year period under review. In most cases the tube was thought to be correctly placed when, in fact, it was not: movements of the reservoir bag and the chest can occur with the tube in the oesophagus. After pre-oxygenation especially, it may be a long time before the patient's colour changes, much less before cardiac arrest takes place. If there be the slightest doubt as to where the Iracheal tube has been placed it should be removed immediately: "When in doubt take it out."

A second type of disaster occurs, but is less common: here the anaesthetist undertakes tracheal intubation with a technique inappropriate to the conditions as, for example, when thiopentone and suxamethonium are used in patients with gross respiratory obstruction due to Ludwig's angina. It is worth mentioning that, on occasion, prolonged and increasingly desperate 
TABLE VI

Analysis of 19 Cases of Death and Cerebral Damage Due to the Use of a Pulmonary Ventilarot

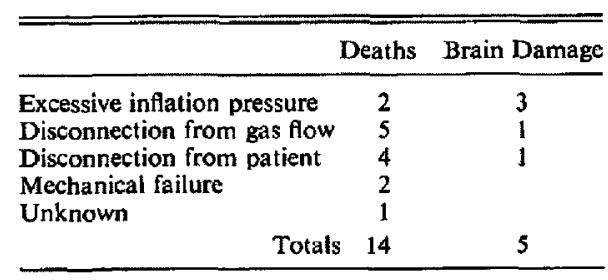

attempts are made to intubate the trachea in conditions where the indications for this technique are only marginal in the first place.

This sort of information raises important questions about the teaching of anaesthesia. Every teacher should surely ask himself if he gives sufficient emphasis to the problems involved in tracheal intubation and its hazards. It is a manoeuvre so commonly employed as to diminish both the respect it deserves and the care it demands. There is sometimes, perhaps, too great a tendency to teach about the esoteric and the rare at the expense of emphasizing the importance of scrupulous attention to technique.

Misuse of apparatus was the second most common cause of death and cerebral damage due to faulty techniques. Of the 40 cases of death or cerebral damage in this group 19 were due to accidents with lung ventilators. Table VI gives an analysis of these accidents. It can be seen that the main cause of death and cerebral damage attributed to pulmonary ventilation was not an abstruse form of mechanical failure. Over half of the catastrophes occurred for no more complicated a reason that that the ventilator became disconnected from the gas flow, or the patient from the ventilator.

It is possible to argue that any anaesthetist, however competent he may be, will eventually lose the life of a patient from acidaspiration, if he be unfortunate. No apology is needed for putting the 22 cases of acid aspiration in the group of faulty technique; however, since in each of these cases some reasonable precaution was omitted. for example, there was no adequate sucker available, pre-cricoid pressure was not employed, no pre-anaesthetic antacid was given.

Induced hypotension caused 16 of the cases of death and cerebral damage. Though safe in the hands of the expert, this technique is devastating in the hands of the inexperienced. In some of the cases in which induced hypotension caused death
TABLE VII

Cases of Death and of Cerebral Damage Which Were Thought to Be DUe VIRTUALLy EXClusively TO THE Disease Process INYolved ANALYSED A CCORDing to the Disease Process lnvolved

\begin{tabular}{|c|c|c|}
\hline & Deaths & $\begin{array}{l}\text { Cerebral } \\
\text { Damage }\end{array}$ \\
\hline Cardio-respiratory disease & 21 & 3 \\
\hline Renal disease & 2 & - \\
\hline Infection & 2 & - \\
\hline Postop. vomiting & $\overline{1}$ & - \\
\hline Stab wound to neck & 1 & - \\
\hline Head injury & 1 & - \\
\hline Muscular dystrophy & 1 & - \\
\hline Subarachnoid haemorrhage & 1 & - \\
\hline Disseminated sclerosis & - & - \\
\hline Intracranial tumour (coning) & 1 & - \\
\hline \multicolumn{3}{|l|}{ Phaeochromocytoma } \\
\hline (undiagnosed) & 1 & - \\
\hline Ulcerative colitis & 1 & - \\
\hline Drug addiction (methadone) & 1 & - \\
\hline Totals & s 34 & 3 \\
\hline
\end{tabular}

or cerebral damage no effort had ever been made to measure the arterial blood pressure.

Among the cases designated here as hypoxia ( 16 cases) were many in which the oxygen cylinder ran out. This has been distinguished from using nitrous oxide instead of oxygen (6 cases). corbon dioxide instead of oxygen (4 cases) and airuay obstruction (4 cases). The use of halothane with adrenaline. the production of $a c$ cidental pneumothorax by using apparatus in the wrong way and error in giving epidural analgesia complete the list of deaths and cerebral damage due to faulty techniques.

\section{Co-existing disease}

The second commonest cause of death and cerebral damage in this series (Table $V$ ) was due to the co-existing disease. These co-existing diseases are mentioned in Table VII. The overwhelming pre-eminence of cardio-respiratory disease in this group will come as no surprise.

\section{Unknown causes}

In a very considerable number of cases the cause of death was unknown. A brief look at Table VIII suggests that death without apparent reason is more common in the dental chair than elsewhere. This may possibly be true; it may be that some as yet undetermined factor may be at work in anaesthesia in the dental chair. It must be remembered, however, that a vast number of dental anaesthetics are given in the United Kingdom and that Table VIII may just reflect this fact. 
TABLE VIII

Cases of Death and Cerebral Damage for Which No Obvious Cause Could Be Founo Broken Down Into Those Occurring in the Dental Chalr and THOSE OCCURRING ElSEWHERE

\begin{tabular}{|c|c|c|}
\hline & Deaths & $\begin{array}{l}\text { Cerebral } \\
\text { Damage }\end{array}$ \\
\hline \multirow[t]{2}{*}{$\begin{array}{l}\text { Dental Chair } \\
\text { Other }\end{array}$} & $\begin{array}{l}16 \\
13\end{array}$ & $\begin{array}{l}2 \\
5\end{array}$ \\
\hline & Totals 29 & 7 \\
\hline
\end{tabular}

TABLE IX

Causes of Death and Cerearal Damage in the Immediate Postoperative Period

\begin{tabular}{|c|c|c|c|}
\hline & & Deaths & $\begin{array}{l}\text { Cerebral } \\
\text { Damage }\end{array}$ \\
\hline \multirow{5}{*}{$\begin{array}{l}\text { Obstructed airway } \\
\text { Respiratory depression } \\
\text { Hypotension } \\
\text { Fall from table }\end{array}$} & & 18 & 3 \\
\hline & & 7 & 1 \\
\hline & & 3 & - \\
\hline & & - & 1 \\
\hline & Totals & 28 & 5 \\
\hline
\end{tabular}

\section{Posfoperative problems}

The anaesthetist's responsibility does not end in the operating room. though he need not, perhaps, always take the blame for failure of postoperative care. Nevertheless the main cause of death and cerebral damage in the immediate postoperative period was obstruction of the airway (Table IX). After an operation the anaesthetist has to assure himself that the patient is able to look after his own airway or is put in the care of someone who is as able to look after the airway as the anaesthetist. It may be that the frequency of trouble postoperatively is due to failure to provide well-trained staff housed in adequate postoperative recovery rooms. Too often the anaesthetist hands over a patient who has not recovered completely to staff who are relatively untrained.

\section{Others}

Drug averdose is an obvious but avoidable cause of death and cerebral damage. Injudiciously large doses of intravenous induction agents. for example, are still given quite frequently.

Drug sensitivity, on the other hand, involves a grossly abnormal response to a normal dose of drug. This is not the place to stray into a discussion of the various merits or demerits of the intravenous induction agents; acute hypotension, bronchospasm and cardiac arrest after propanidid is, however, represented in this group by more than one case, as is Althesin. Whether this is a genuinely high incidence of adverse reaction has yet to be decided.

Halothane hepatic failure is given a question mark for obvious reasons. Millions of words must have been written on this subject by now, and yet we seem little further towards the truth than we were. Hyperthermia again is a subject of controversy. Presumably a few years ago patients who died of malignant hyperpyrexia would have been classified in the group of unknown causes.

Failure of preoperative assessment involves situations in which the patient died or suffered cerebral damage because pre-existing conditions were missed. A male patient of $70 \mathrm{~kg}$. for example, was subjected to elective gastrectomy hut died some days after operation on a ventilator. It was not remembered that he had an FEV of $800 \mathrm{ml}$; though the investigation had been done a month before it had been forgotten.

Blood loss accounted for six deaths only; though here, again, the incidence of reporting is probably low. Not infrequently there is a temptation to start an operation before blood is available, just because it is convenient.

Few can contemplate with equanimity the possibility of using the wrong drugs. Most of us must be frightened of doing so. One must feel great sympathy with the registrar who committed the error of giving a gram of potassium to a fiveyear-old child instead of atropine $1.2 \mathrm{mg}$ and neostigmine $5.0 \mathrm{mg}$ to reverse neuromuscular block; and with the several anaesthetists who have attempted to clear intravenous infusions with potassium, or used adrenaline instead of atropine. Nevertheless drug error of this sort is indefensible. It is so simple to check the ampoule and to have it double-checked.

Indefensible, too, is the situation which is here called andesthetist's failure: the anaesthetist left the operating department to make a telephone call or even to have a cup of coffee and something went wrong with the patient. Embolism featured perhaps less commonly than might be expected. and clot in a by-pass is too specialized, and too uncommon, to require special mention.

\section{Misadventure}

The title of this paper is "Human Misadventure in Anaesthesia". Excluding considerations of the law which deals with misadventure in a special way. "misadventure" is usually taken to 
TABLE X

Causes of Death and Cerebral Damage Classified lnto Those Apparently Due to MISAdventure and THOSE APPARENTLY DUE TO ERROR

\begin{tabular}{|c|c|c|c|}
\hline $\begin{array}{c}\text { Mainly } \\
\text { misadventure }\end{array}$ & $\%$ & $\begin{array}{l}\text { Mainly } \\
\text { error }\end{array}$ & $\%$ \\
\hline $\begin{array}{l}\text { Co-existing disease } \\
\text { Unknown }\end{array}$ & $\begin{array}{l}10.6 \\
10.3\end{array}$ & $\begin{array}{l}\text { Faulty technique } \\
\text { Failure postop. }\end{array}$ & 46.8 \\
\hline $\begin{array}{l}\text { Drug sensitivity } \\
\text { Halothane hepatic }\end{array}$ & 4.6 & $\begin{array}{l}\text { care } \\
\text { Drug overdose }\end{array}$ & $\begin{array}{l}9.5 \\
5.2\end{array}$ \\
\hline $\begin{array}{l}\quad \text { failure (?) } \\
\text { Hyperthermia } \\
\text { Blood loss }\end{array}$ & $\begin{array}{l}3.4 \\
2.9 \\
1.7\end{array}$ & $\begin{array}{l}\text { Failure of preop. } \\
\text { assessment } \\
\text { Drug error }\end{array}$ & $\begin{array}{l}1.4 \\
1.4\end{array}$ \\
\hline $\begin{array}{l}\text { Embolism } \\
\text { Clot in by-pass }\end{array}$ & $\begin{array}{l}0.9 \\
0.3\end{array}$ & failure & 1.4 \\
\hline Total & 34.7 & Total & 65.7 \\
\hline
\end{tabular}

be an unlucky chance or accident. In these terms being struck by lightning is the supreme misadventure: one is not able to protect oneself adequately against misadventure.

"Human misaidventure in anaesthesia", however, though it undoubtedly occurs, does not feature as frequently in medico-legal work of this sort as does human failure. Table $X$ divides the cases of death and cerebral damage already presented into two classes; those due mainly to misadventure and those due mainly to error. One may quarrel with some of the judgements made, but this need not obscure the basic fact that errors are about twice as common as are misadventures.

There are many causes of human failure; failure due to laziness and slackness (by omitting adequate preoperative assessment), failure due to pride (for example by omitting to take advice). failure due to boredom (when vigilance will fail). Most important of all, perhaps, is failure to teach the ordinary by concentrating too much on the esoteric.

\section{SUMMARY}

An account is given of the 602 anaesthetic accidents reported to the Medical Defence Union of the United Kingdom over the eight-year period 1970-1977: these were reported from a total membership of 2,000 anaesthetists. It is known that reporting of minor accidents, for example damage to teeth, is very imcomplete, and that many deaths associated with surgery but due to disease processes rather than anaesthesia would not be reported either. It is thought, however, that the reporting by members of other accidents involving death and cerebral damage is likely to be complete, or nearly so.

Cascs of death and cerebral damage reported numbered 348 ( 60 per cent of the total) and the causes of these two major accidents were so closely similar that it was possible to deal with them together. This appears to be a suitable approach since cerebral damage can be as great, or greater, a catastrophe than death. In nearly half of this group of accidents there was discernibly faulty technique. Failure of postoperative care ( 10 per cent of the 348 cases) was another prominent and avoidable cause.

Analysis of the faulty anaesthetic techniques which led to these major accidents showed that factors involved in tracheal intubation were preeminent, and that misuse of apparatus was also conspicuous. Over all error was deemed to be twice as common a cause of death and cerebral damage as was misadventure.

\section{RÉSUMÉ}

Entre 1970 et 1977, 602 accidents anesthésiques ont été rapportés au Medical Defense Union qui représente environ 87,000 médecins et dentistes (dont 2,000 anesthésistes) dans les cas de poursuites liées à la pratique de leur profession.

I] est clair que ce total ne représente pas la totalité des accidents survenus. En effet, beaucoup d'accidents mineurs. comme les traumatismes dentaires. ne sont probablement pas rapportés. De mème, on ne rapporte généralement pas les décès clairement liés à une pathologie pré-existante. Par ailleurs, il apparait probable que la presque totalité des accidents suivis de décès ou de dommages cérébraux sont effectivement rapportés.

De tels accidents (suivis de décès ou de dommages cérébraux) représentaient 60 pour cent du total, soit 318 cas sur 602. Les causes de ces deux types d'accidents étaient si semblables que l'on a choisi de les considérer dans un méme ensemble. Cette approche apparait justifiée lorsque l'on considère qu'un cas de dommage cérébral peut ètre aussi catastrophique qu'un décès.

Dans près de la moitié de ces accidents graves. on a pu mettre en évidence une faute technique (tube trachéal dans l'uesophage ou incapacité d'intuber et de ventiler un malade obstrué après l'avoir endormi et curarisé, aspiration de contenu gastrique, respirateur ou tubes dappareil d'anesthésie débranchés, cylindres d'oxygène épuisés, usage du proloxyde d'azote alors que 
l'on croyait utiliser l'oxygène, etc). Dix pour cent des cas sont survenus en phase post-opératoire (surtout des problèmes d'obstruction des voies aériennes. Par comparaison aux situations peu prévisibles (hyperthermie maligne, hépatites à I'halothane) reliées à la pathologie préexistante, l'erreur humaine était en cause dans une proportion de deux pour un.

\section{REFERENCES}

BeEcher, H.K. \& Tood. D.P. A study of the deaths associated with anesthesia and surgery based on a study of 599.548 anesthesias in ten institutions 1948-1952. inclusive. Ann. Surg. 140: 2-35 (1954).

Boba, A. Death in the Operating Room. Springfield. Ill. Charles C. Thomas (1965).
Chifton, B.S. \& Hotten, W.I.T. Deaths associated with anesthesia. Br. J. Anaesth. 35: 250-259 (1963).

COOPER, J.B.. NeWBower, R.S., LONG, C.D. \& MCPEeK. B. Preventable anesthesia mishaps: a study of human factors. Anesthesiology, 49: 399-406 (1978).

Dripps, R.D., Lamont, A. \& Eckenhoff, J.E. The role of anesthesia in surgical mortality. J.A.M.A. 178: 261-266(1961).

Edwards, G.. Morton, H.J.V. \& Pask. E.A.. et $a l$ Deaths associated with anesthesia: report on 1,000 cases. A naesthesia $/ l: 194-220$ (1956).

PhILlips, O.C. \& CAMZZI, L.S. Anesthesia mortality. Clin. Anesth. 10:220-244 (1974).

Taylor, G., Larson, C.P. \& Prestwich, R. Unexpected cardiac arrest during anesthesia and surgery. J.A.M.A. 236: 2758-2760 (1976).

WYLIE, W.D. There, but for the grace of God ... Ann Roy. Coll. Surg. S6: 171-180 (1975). 